\title{
Description of Olleya aquimaris sp. nov., isolated from seawater, and emended description of the genus Olleya Mancuso Nichols et al. 2005
}

Correspondence Jung-Hoon Yoon jhyoon@kribb.re.kr
Soo-Young Lee, Sooyeon Park, Tae-Kwang Oh and Jung-Hoon Yoon

Korea Research Institute of Bioscience and Biotechnology (KRIBB), PO Box 115, Yusong, Taejon, Republic of Korea
The genus Olleya was created by Mancuso Nichols et al. (2005) with Olleya marilimosa as the sole recognized species. Members of the genus Olleya can be distinguished from closely related members of the family Flavobacteriaceae on the basis of low 16S rRNA gene sequence similarities and differences in DNA G $+\mathrm{C}$ content and fatty acid profile (Mancuso Nichols et al., 2005). In this study, a novel bacterial strain, designated $\mathrm{L}-4^{\mathrm{T}}$, isolated from seawater of Baekdo harbour in the East Sea, Korea, is described. Comparative 16S rRNA gene sequence analysis indicated that, phylogenetically, strain $\mathrm{L}-4^{\mathrm{T}}$ is most closely related to members of the genus Olleya. The aim of the present work was to determine the exact taxonomic position of strain $\mathrm{L}-4^{\mathrm{T}}$ by using a polyphasic approach that included determination of phenotypic properties and a detailed phylogenetic investigation based on 16S rRNA gene sequences.

The standard dilution plating technique was used for isolation of bacterial strains from seawater samples. Strain $\mathrm{L}-4^{\mathrm{T}}$ was isolated on marine agar 2216 (MA; Difco) at $25{ }^{\circ} \mathrm{C}$ and cultivated routinely on MA at $37{ }^{\circ} \mathrm{C}$. O. marilimosa CIP $108537^{\mathrm{T}}$ was used as a reference strain for

The GenBank/EMBL/DDBJ accession number for the 16S rRNA gene sequence of strain $L-4^{\top}$ is FJ886713.
DNA-DNA hybridization, phenotypic characterization and analyses of fatty acids, polar lipids and isoprenoid quinones. Cell morphology was examined by using light microscopy (E600; Nikon) and transmission electron microscopy (CM-20; Philips). The presence of flagella was assessed by using transmission electron microscopy of cells from an exponentially growing culture. For this purpose, cells were negatively stained with $1 \%(\mathrm{w} / \mathrm{v})$ phosphotungstic acid and grids were examined after being air-dried. Gliding motility was investigated as described by Bowman (2000). The Gram reaction was determined using the bioMérieux Gram stain kit according to the manufacturer's instructions. Growth at 4, 15, 20, 25, 30, 37, 40 and $45{ }^{\circ} \mathrm{C}$ was measured on MA. The $\mathrm{pH}$ range for growth was investigated in marine broth 2216 (MB; Difco) adjusted to $\mathrm{pH} 4.0-10.0$, in increments of $0.5 \mathrm{pH}$ units, by using sodium acetate/acetic acid and $\mathrm{Na}_{2} \mathrm{CO}_{3}$ buffers. Growth in the absence of $\mathrm{NaCl}$ and in the presence of 0.5 , 1.0, 2.0 and $3.0 \%(\mathrm{w} / \mathrm{v}) \mathrm{NaCl}$ was investigated in trypticase soy broth prepared according to the formula of the Difco medium except that $\mathrm{NaCl}$ was omitted and $0.45 \%(\mathrm{w} / \mathrm{v})$ $\mathrm{MgCl}_{2} .6 \mathrm{H}_{2} \mathrm{O}$ or $0.06 \%(\mathrm{w} / \mathrm{v}) \mathrm{KCl}$ was added. Growth in the presence of $2.0-8.0 \%(\mathrm{w} / \mathrm{v}) \mathrm{NaCl}$ (in increments of $1.0 \%$ ) was investigated in MB. Growth under anaerobic conditions was investigated in a Forma anaerobic chamber 
on MA and on MA supplemented with $0.1 \%$ (w/v) potassium nitrate, both of which had been prepared anaerobically under a nitrogen atmosphere. Catalase and oxidase activities were determined as described by Cowan \& Steel (1965). Hydrolysis of casein, hypoxanthine, starch, xanthine, tyrosine and Tweens 20,40, 60 and 80 was examined on MA using substrate concentrations described previously (Cowan \& Steel, 1965). Nitrate reduction and hydrolysis of aesculin, gelatin and urea were assessed as described by Lányí (1987) with the modification that artificial seawater [containing (per litre distilled water) $23.6 \mathrm{~g} \mathrm{NaCl}, 0.64 \mathrm{~g} \mathrm{KCl}, 4.53 \mathrm{~g} \mathrm{MgCl}_{2} .6 \mathrm{H}_{2} \mathrm{O}, 5.94 \mathrm{~g}$ $\mathrm{MgSO}_{4} .7 \mathrm{H}_{2} \mathrm{O}$ and $1.3 \mathrm{~g} \mathrm{CaCl}_{2} .2 \mathrm{H}_{2} \mathrm{O}$; Bruns et al., 2001] was used for preparation of media. The presence of flexirubin-type pigments was investigated as described by Reichenbach (1992). Cellulase and xylanase activities were assessed by staining with a $0.1 \%(\mathrm{w} / \mathrm{v})$ Congo red aqueous solution after incubation on MA supplemented with $0.5 \%$ (w/v) CM-cellulose (Sigma) or xylan (Sigma), respectively. Utilization of various substrates as sole carbon and energy sources was tested as described by Baumann \& Baumann (1981) using supplementation with $2 \%(\mathrm{v} / \mathrm{v})$ Hutner's mineral salts solution (Cohen-Bazire et al., 1957) and $1 \%$ $(\mathrm{v} / \mathrm{v})$ vitamin solution (Staley, 1968). Acid production from carbohydrates was assessed as described by Leifson (1963). Susceptibility to antibiotics was tested on MA plates using antibiotic discs containing the following (in $\mu \mathrm{g}$ except where indicated): ampicillin (10); carbenicillin (100); cephalothin (30); chloramphenicol (100); gentamicin (30); kanamycin (30); lincomycin (15); neomycin (30); novobiocin (5); oleandomycin (15); penicillin G (20 U); polymyxin B (100 U); streptomycin (50); and tetracycline (30). Enzyme activities were assessed and additional biochemical tests were performed by using the API ZYM and API 20E systems (bioMérieux) incubated at $37{ }^{\circ} \mathrm{C}$ according to the manufacturer's instructions. Morphological, cultural, physiological and biochemical properties of strain $\mathrm{L}-4^{\mathrm{T}}$ are given in the species description and in Table 1.

Cell biomass for DNA extraction and for the analyses of isoprenoid quinones and polar lipids was obtained from cultures grown for 3 days in $\mathrm{MB}$ at $37^{\circ} \mathrm{C}$. Chromosomal DNA was extracted and purified according to the method described by Yoon et al. (1996) with the modification that RNase T1 was used in combination with RNase A to minimize contamination by RNA. 16S rRNA gene amplification was performed using two universal primers as described previously (Yoon et al., 1998) and the PCR products were purified by using a QIAquick PCR purification kit (Qiagen). Sequencing of the amplified $16 \mathrm{~S}$ rRNA gene and phylogenetic analysis were performed as described by Yoon et al. (2003). Isoprenoid quinones were analysed as described by Komagata \& Suzuki (1987) using reversed-phase HPLC and a YMC ODS-A $(250 \times 4.6 \mathrm{~mm})$ column. Polar lipids were extracted according to the procedures described by Minnikin et al. (1984) and identified by two-dimensional TLC followed by
Table 1. Differential phenotypic characteristics of strain $L-4^{\top}$ and O. marilimosa CIP $108537^{\top}$

Strains: 1 , Olleya aquimaris sp. nov. L-4 $4^{\mathrm{T}} ; 2$, O. marilimosa CIP $108537^{\mathrm{T}}$. All data are from this study except for growth at $37{ }^{\circ} \mathrm{C}$, anaerobic growth and spore formation for O. marilimosa; these data are from Mancuso Nichols et al. (2005). +, Positive; w, weakly positive; -, negative. Both strains are positive for: gliding motility; hydrolysis of gelatin and Tweens 20, 40, 60 and 80; acid production from maltose and sucrose; susceptibility to carbenicillin, chloramphenicol, lincomycin, novobiocin and oleandomycin; and catalase, oxidase, alkaline phosphatase, esterase lipase (C8), leucine arylamidase, cystine arylamidase, acid phosphatase and naphthol-AS-BI-phosphohydrolase activities. Both strains are negative for: anaerobic growth; Gram-staining; spore formation; production of flexirubin-type pigments; nitrate reduction; hydrolysis of agar, hypoxanthine and xanthine; production of acetoin, $\mathrm{H}_{2} \mathrm{~S}$ and indole; utilization of cellobiose, D-fructose, D-galactose, sucrose, trehalose, D-xylose, acetate, benzoate, formate, L-malate, pyruvate, succinate, salicin and L-glutamate; acid production from L-arabinose, cellobiose, D-fructose, D-galactose, myo-inositol, lactose, D-mannitol, melezitose, melibiose, raffinose, L-rhamnose, D-ribose, D-sorbitol and Dxylose; susceptibility to ampicillin, gentamicin, kanamycin, neomycin, penicillin $\mathrm{G}$, polymyxin $\mathrm{B}$, streptomycin and tetracycline; and cellulase (CM-cellulose), xylanase, urease, arginine dihydrolase, lysine decarboxylase, ornithine decarboxylase, tryptophan deaminase, lipase (C14), trypsin, $\alpha$-galactosidase, $\beta$-galactosidase, $\beta$-glucuronidase, $\alpha$-glucosidase, $\beta$-glucosidase, $\alpha$-mannosidase and $\alpha$-fucosidase activities.

\begin{tabular}{|c|c|c|}
\hline Characteristic & 1 & 2 \\
\hline Growth at $37{ }^{\circ} \mathrm{C}$ & + & - \\
\hline \multicolumn{3}{|l|}{ Hydrolysis of: } \\
\hline Starch & + & - \\
\hline L-Tyrosine & - & + \\
\hline Aesculin & + & $+^{*}$ \\
\hline Casein & + & $+^{*}$ \\
\hline \multicolumn{3}{|l|}{ Utilization of: } \\
\hline L-Arabinose & + & - \\
\hline D-Mannose & - & + \\
\hline Citrate & - & w \\
\hline D-Glucose & - & $-\dagger$ \\
\hline Maltose & - & $-\dagger$ \\
\hline \multicolumn{3}{|l|}{ Acid production from: } \\
\hline D-Glucose & - & + \\
\hline D-Mannose & - & $\mathrm{w}$ \\
\hline Trehalose & + & - \\
\hline Susceptibility to cephalothin & + & - \\
\hline \multicolumn{3}{|l|}{ Activity of (API ZYM): } \\
\hline Esterase (C4) & + & - \\
\hline Valine arylamidase & - & + \\
\hline$\alpha$-Chymotrypsin & + & - \\
\hline$N$-Acetyl- $\beta$-glucosaminidase & - & $-\dagger$ \\
\hline Major polar lipids $\ddagger$ & $1 \mathrm{AL}, 2 \mathrm{~L}$ & $1 \mathrm{AL}, 1 \mathrm{~L}$ \\
\hline DNA G $+C$ content $(\mathrm{mol} \%)$ & 35 & $42 \S$ \\
\hline
\end{tabular}

${ }^{\star}$ Reported as negative by Mancuso Nichols et al. (2005).

$\nmid$ Reported as positive by Mancuso Nichols et al. (2005).

$\ddagger$ AL, Unidentified aminolipid; L, unidentified lipid.

$\S$ Data from this study obtained by the HPLC method; value of $49 \mathrm{~mol} \%$ (thermal denaturation method) reported for O. marilimosa CAM $030^{\mathrm{T}}$ by Mancuso Nichols et al. (2005). 
spraying with the appropriate detection reagents (Minnikin et al., 1984; Komagata \& Suzuki, 1987). For cellular fatty acid analysis, cell mass of strain $\mathrm{L}-4^{\mathrm{T}}$ and $O$. marilimosa CIP $108537^{\mathrm{T}}$ was harvested from MA plates after cultivation for 3 days at $30{ }^{\circ} \mathrm{C}$. Fatty acids were extracted and fatty acid methyl esters were prepared according to the standard protocol of the MIDI/Hewlett Packard Microbial Identification System (Sasser, 1990). The DNA G +C content was determined by the method of Tamaoka \& Komagata (1984) with the modification that DNA was hydrolysed using nuclease P1 (Sigma) and the resultant nucleotides were analysed by reversed-phase HPLC. DNADNA hybridization was performed fluorometrically by the method of Ezaki et al. (1989) using photobiotin-labelled DNA probes and microdilution wells. Hybridization was performed with five replications for each sample. The highest and lowest values obtained for each sample were excluded and the means of the remaining three values are quoted as DNA-DNA relatedness values.

The almost-complete 16S rRNA gene sequence of strain $\mathrm{L}-4^{\mathrm{T}}$ determined in this study comprised $1443 \mathrm{bp}$, representing approximately $96 \%$ of the Escherichia coli $16 \mathrm{~S}$ rRNA gene sequence. In the phylogenetic tree constructed using the neighbour-joining algorithm, strain $\mathrm{L}-4^{\mathrm{T}}$ joined O. marilimosa CAM030 ${ }^{\mathrm{T}}$, a member of the family Flavobacteriaceae, with a bootstrap confidence value of $98.5 \%$ (Fig. 1). The relationship between strain $\mathrm{L}-4^{\mathrm{T}}$ and O. marilimosa CAM $030^{\mathrm{T}}$ was also found in phylogenetic trees constructed using the maximum-likelihood and maximum-parsimony algorithms. Strain $\mathrm{L}-4^{\mathrm{T}}$ exhibited
97.2 \% 16S rRNA gene sequence similarity to O. marilimosa CAM030 ${ }^{\mathrm{T}}, 94.4-95.8 \%$ to the type strains of Lacinutrix species and less than $95.4 \%$ to strains of other species used in the phylogenetic analysis.

The predominant isoprenoid quinone of strain $\mathrm{L}-4^{\mathrm{T}}$ and $O$. marilimosa CIP $108537^{\mathrm{T}}$ was MK-6, which is in line with all other members of the family Flavobacteriaceae (Bernardet \& Nakagawa, 2006). The cellular fatty acid profile of strain $\mathrm{L}-4^{\mathrm{T}}$ is shown in Table 2, together with that of $O$. marilimosa CIP $108537^{\mathrm{T}}$, which was also analysed in this study. The fatty acid profiles of the two strains were similar, although differences were observed in the proportions of some fatty acids (Table 2). The polar lipid profiles of the two strains were also similar. The major polar lipids of both strains were an unidentified aminolipid and one (O. marilimosa CIP $108537^{\mathrm{T}}$ ) or two (strain L-4 $4^{\mathrm{T}}$ ) unidentified lipids. The DNA G $+\mathrm{C}$ content of strain $\mathrm{L}-4^{\mathrm{T}}$ was $35 \mathrm{~mol} \%$, a value that was distinctly lower than that reported for O. marilimosa (Mancuso Nichols et al., 2005).

The mean DNA-DNA relatedness between strain $\mathrm{L}-4^{\mathrm{T}}$ and O. marilimosa CIP $108537^{\mathrm{T}}$ was $7 \%$. Strain L-4 $4^{\mathrm{T}}$ could also be differentiated from $O$. marilimosa by differences in several phenotypic characteristics, including growth at $37{ }^{\circ} \mathrm{C}$, hydrolysis of starch and L-tyrosine, utilization of and acid production from several substrates, activity of various enzymes and susceptibility to cephalothin (Table 1). The phylogenetic and genetic distinctiveness and differential phenotypic properties of strain L- $4^{\mathrm{T}}$ are sufficient to support its classification within a novel species of the genus Olleya, for which the name Olleya aquimaris sp. nov. is proposed.

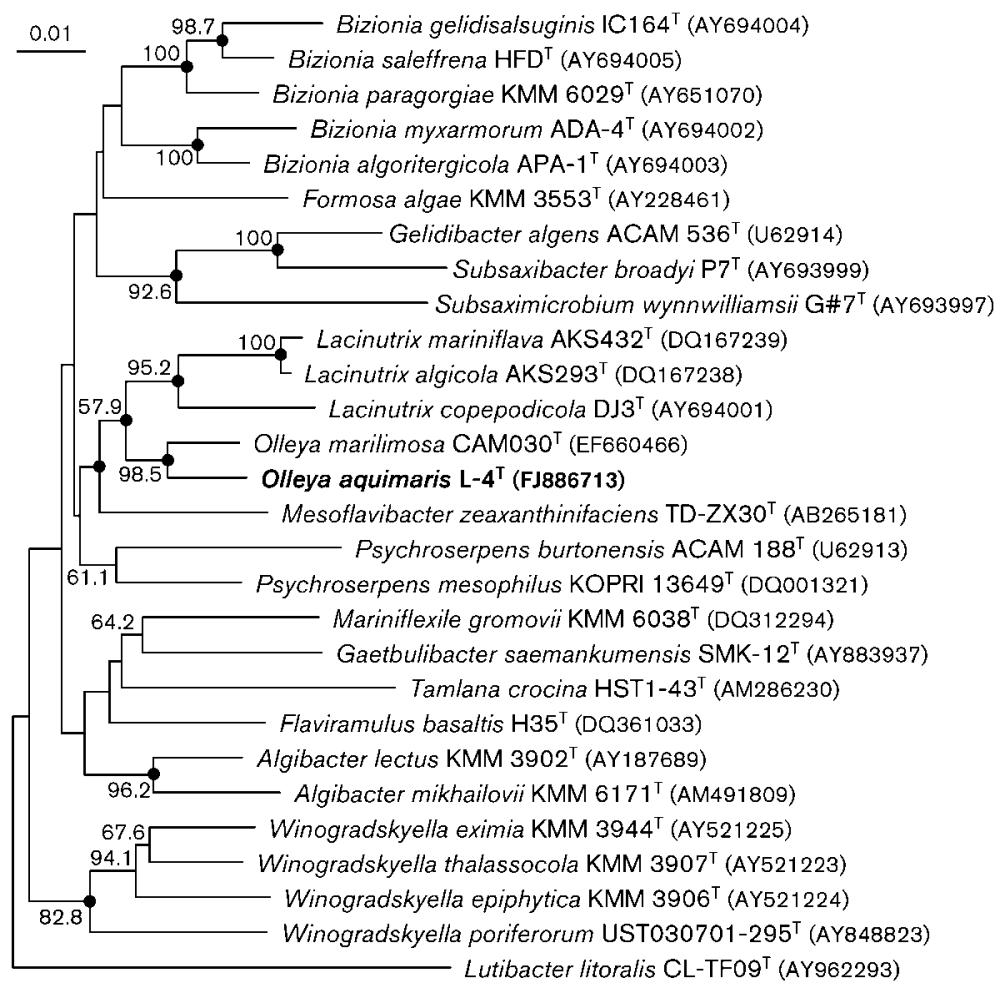

Fig. 1. Neighbour-joining tree based on $16 \mathrm{~S}$ rRNA gene sequences showing the phylogenetic positions of Olleya aquimaris sp. nov. $\mathrm{L}-4^{\top}$, O. marilimosa $\mathrm{CAMO} 30^{\top}$ and related taxa. Bootstrap values (expressed as percentages of 1000 replications) $>50 \%$ are shown at branching points. Filled circles indicate that the corresponding nodes were also recovered in trees generated with the maximum-likelihood and maximum-parsimony algorithms. Lutibacter litoralis CL-TF09 ${ }^{\top}$ was used as an outgroup. Bar, 0.01 substitutions per nucleotide position. 
Table 2. Cellular fatty acid compositions (\%) of strain $L-4^{\top}$ and O. marilimosa CIP $108537^{\top}$

Strains: 1, O. aquimaris $\mathrm{L}-4^{\mathrm{T}} ; 2$, O. marilimosa CIP $108537^{\mathrm{T}}$. Data are from this study. Fatty acids that represent $<1.0 \%$ in both strains were omitted. tr, Trace $(<1 \%)$; - , not detected.

\begin{tabular}{|c|c|c|}
\hline Fatty acid & 1 & 2 \\
\hline \multicolumn{3}{|l|}{ Straight-chain } \\
\hline $\mathrm{C}_{15: 0}$ & 5.2 & 9.1 \\
\hline \multicolumn{3}{|l|}{ Unsaturated } \\
\hline $\mathrm{C}_{15: 1} \omega 6 c$ & - & 2.4 \\
\hline \multicolumn{3}{|l|}{ Branched } \\
\hline iso- $\mathrm{C}_{14: 0}$ & 1.9 & $\operatorname{tr}$ \\
\hline iso- $\mathrm{C}_{15: 0}$ & 17.2 & 16.9 \\
\hline iso- $\mathrm{C}_{15: 1}$ & 15.7 & 15.0 \\
\hline anteiso- $\mathrm{C}_{15: 0}$ & 4.7 & 2.9 \\
\hline anteiso- $\mathrm{C}_{15: 1}$ & 1.7 & 1.4 \\
\hline iso- $\mathrm{C}_{16: 0}$ & 3.7 & $\operatorname{tr}$ \\
\hline iso- $\mathrm{C}_{16: 1}$ & 1.3 & - \\
\hline iso- $\mathrm{C}_{16: 1}$ & - & 1.1 \\
\hline \multicolumn{3}{|l|}{ Hydroxy } \\
\hline $\mathrm{C}_{15: 0} 2-\mathrm{OH}$ & 1.1 & 1.1 \\
\hline $\mathrm{C}_{15: 0} 3-\mathrm{OH}$ & $\operatorname{tr}$ & 2.2 \\
\hline iso- $\mathrm{C}_{15: 0} 3-\mathrm{OH}$ & 5.6 & 12.1 \\
\hline $\mathrm{C}_{16: 0} 3-\mathrm{OH}$ & $\operatorname{tr}$ & 1.2 \\
\hline iso- $\mathrm{C}_{16: 0} 3-\mathrm{OH}$ & 13.7 & 6.2 \\
\hline $\mathrm{C}_{17: 0} 2-\mathrm{OH}$ & 2.0 & 1.2 \\
\hline iso- $\mathrm{C}_{17: 0} 3-\mathrm{OH}$ & 12.0 & 9.9 \\
\hline Summed feature $3^{*}$ & 8.3 & 9.9 \\
\hline
\end{tabular}

*Summed features represent groups of two or three fatty acids that could not be separated by GLC with the MIDI system. Summed feature 3 contained $\mathrm{C}_{16: 1} \omega 7 c$ and/or iso- $\mathrm{C}_{15: 0} 2-\mathrm{OH}$.

\section{Emended description of the genus Olleya Mancuso Nichols et al. 2005}

The description of the genus Olleya is as given by Mancuso Nichols et al. (2005) with the following amendments. The predominant menaquinone is MK-6. Common major polar lipids are an unidentified aminolipid and an unidentified lipid. The DNA $\mathrm{G}+\mathrm{C}$ content is 35$42 \mathrm{~mol} \%$ (by HPLC).

\section{Description of Olleya aquimaris sp. nov.}

Olleya aquimaris (a.qui.ma'ris. L. n. aqua water; L. gen. n. maris of the sea; N.L. gen. n. aquimaris of seawater).

Cells are Gram-stain-negative, non-flagellated, non-endospore-forming and rod-shaped $(0.5-0.6 \mu \mathrm{m}$ in diameter and $0.6-3.5 \mu \mathrm{m}$ long). Motile by gliding. Strictly aerobic. Flexirubin-type pigments are not produced. Colonies on MA are circular, raised to slightly convex, glistening, smooth, yellow and $0.8-2.2 \mathrm{~mm}$ in diameter after incubation for 3 days at $37^{\circ} \mathrm{C}$. Optimal growth at $37^{\circ} \mathrm{C}$; growth occurs at 4 and $40{ }^{\circ} \mathrm{C}$, but not at $45{ }^{\circ} \mathrm{C}$. Optimal pH for growth is between 6.5 and 7.0; growth occurs at $\mathrm{pH} 6.0$, but not at $\mathrm{pH}$ 5.5. Growth occurs in the presence of $0.5-$ $7.0 \%(\mathrm{w} / \mathrm{v}) \mathrm{NaCl}$ with optimum growth at approximately $2.0 \%(\mathrm{w} / \mathrm{v}) \mathrm{NaCl} . \mathrm{Mg}^{2+}$ ions are required for growth. Catalase- and oxidase-positive. Nitrate is not reduced to nitrite. Aesculin, casein, gelatin, starch and Tweens 20, 40, 60 and 80 are hydrolysed, but CM-cellulose, hypoxanthine, L-tyrosine, urea, xanthine and xylan are not. Acetoin, $\mathrm{H}_{2} \mathrm{~S}$ and indole are not produced. The predominant menaquinone is MK-6. The major polar lipids are an unidentified aminolipid and two unidentified lipids. The major cellular fatty acids $\left(>10 \%\right.$ of the total fatty acids) are iso- $\mathrm{C}_{15: 0}$, iso- $\mathrm{C}_{15: 1}$, iso- $\mathrm{C}_{16: 0} 3-\mathrm{OH}$ and iso- $\mathrm{C}_{17: 0} 3-\mathrm{OH}$. Other phenotypic characteristics are given in Table 1.

The type strain is $\mathrm{L}-4^{\mathrm{T}}\left(=\right.$ KCTC $22661^{\mathrm{T}}=$ CCUG $\left.58074^{\mathrm{T}}\right)$, isolated from seawater of Baekdo harbour in the East Sea, Korea. The DNA $\mathrm{G}+\mathrm{C}$ content of the type strain is $35 \mathrm{~mol} \%$.

\section{Acknowledgements}

This work was supported by the Program for Collection, Management and Utilization of Biological Resources (grant M10867010003) and the 21C Frontier Program of Microbial Genomics and Applications (grant MG05-0401-2-0) from the Ministry of Education, Science and Technology (MEST) of the Republic of Korea.

\section{References}

Baumann, P. \& Baumann, L. (1981). The marine Gram-negative eubacteria: genera Photobacterium, Beneckea, Alteromonas, Pseudomonas, and Alcaligenes. In The Prokaryotes, pp. 1302-1331. Edited by M. P. Starr, H. Stolp, H. G. Trüper, A. Balows \& H. G. Schlegel. Berlin: Springer.

Bernardet, J.-F. \& Nakagawa, Y. (2006). An introduction to the family Flavobacteriaceae. In The Prokaryotes: a Handbook on the Biology of Bacteria, 3rd edn, vol. 7, pp. 455-480. Edited by M. Dworkin, S. Falkow, E. Rosenberg, K. H. Schleifer \& E. Stackebrandt. New York: Springer.

Bowman, J. P. (2000). Description of Cellulophaga algicola sp. nov., isolated from the surfaces of Antarctic algae, and reclassification of Cytophaga uliginosa (ZoBell and Upham 1944) Reichenbach 1989 as Cellulophaga uliginosa comb. nov. Int J Syst Evol Microbiol 50, 18611868.

Bruns, A., Rohde, M. \& Berthe-Corti, L. (2001). Muricauda ruestringensis gen. nov., sp. nov., a facultatively anaerobic, appendaged bacterium from German North Sea intertidal sediment. Int $J$ Syst Evol Microbiol 51, 1997-2006.

Cohen-Bazire, G., Sistrom, W. R. \& Stanier, R. Y. (1957). Kinetic studies of pigment synthesis by nonsulfur purple bacteria. J Cell Comp Physiol 49, 25-68.

Cowan, S. T. \& Steel, K. J. (1965). Manual for the Identification of Medical Bacteria. London: Cambridge University Press.

Ezaki, T., Hashimoto, Y. \& Yabuuchi, E. (1989). Fluorometric deoxyribonucleic acid-deoxyribonucleic acid hybridization in microdilution wells as an alternative to membrane filter hybridization in which radioisotopes are used to determine genetic relatedness among bacterial strains. Int J Syst Bacteriol 39, 224 229. 
Komagata, K. \& Suzuki, K. (1987). Lipid and cell-wall analysis in bacterial systematics. Methods Microbiol 19, 161-207.

Lányí, B. (1987). Classical and rapid identification methods for medically important bacteria. Methods Microbiol 19, 1-67.

Leifson, E. (1963). Determination of carbohydrate metabolism of marine bacteria. J Bacteriol 85, 1183-1184.

Mancuso Nichols, C., Bowman, J. P. \& Guezennec, J. (2005). Olleya marilimosa gen. nov., sp. nov., an exopolysaccharide-producing marine bacterium from the family Flavobacteriaceae, isolated from the Southern Ocean. Int J Syst Evol Microbiol 55, 1557-1561.

Minnikin, D. E., O’Donnell, A. G., Goodfellow, M., Alderson, G., Athalye, M., Schaal, A. \& Parlett, J. H. (1984). An integrated procedure for the extraction of bacterial isoprenoid quinones and polar lipids. J Microbiol Methods 2, 233-241.

Reichenbach, H. (1992). The order Cytophagales. In The Prokaryotes, 2nd edn, vol. 4, pp. 3631-3675. Edited by A. Balows, H. G. Trüper, M. Dworkin, W. Harder \& K. H. Schleifer. New York: Springer.
Sasser, M. (1990). Identification of bacteria by gas chromatography of cellular fatty acids, MIDI Technical Note 101. Newark, DE: MIDI Inc.

Staley, J. T. (1968). Prosthecomicrobium and Ancalomicrobium: new prosthecate freshwater bacteria. J Bacteriol 95, 1921-1942.

Tamaoka, J. \& Komagata, K. (1984). Determination of DNA base composition by reversed-phase high-performance liquid chromatography. FEMS Microbiol Lett 25, 125-128.

Yoon, J.-H., Kim, H., Kim, S.-B., Kim, H.-J., Kim, W. Y., Lee, S. T., Goodfellow, M. \& Park, Y.-H. (1996). Identification of Saccharomonospora strains by the use of genomic DNA fragments and rRNA gene probes. Int J Syst Bacteriol 46, 502-505.

Yoon, J.-H., Lee, S. T. \& Park, Y.-H. (1998). Inter- and intraspecific phylogenetic analysis of the genus Nocardioides and related taxa based on 16S rDNA sequences. Int J Syst Bacteriol 48, 187-194.

Yoon, J.-H., Kang, K. H. \& Park, Y.-H. (2003). Psychrobacter jeotgali sp. nov., isolated from jeotgal, a traditional Korean fermented seafood. Int J Syst Evol Microbiol 53, 449-454. 